\title{
Chapter 5 \\ National Approaches to Circular Migration in Bulgaria and Poland
}

This chapter aims to illustrate national variances in instruments conducive to circular migration as part of the implementation of the EU's approach. It serves as an introduction to the two different national approaches to circular migration facilitation developed in Bulgaria and Poland, which were chosen as case studies. First, the chapter examines the respective strategies of these two countries in their preaccession periods that influenced the instruments developed in Bulgaria and Poland. Second, it zooms in on the national contexts in order to put some flesh on the different instruments seen as fostering circular migration at the national level.

\subsection{Bulgaria and Poland: Two Different Pre-accession Conditionality Strategies ${ }^{1}$}

The migration policies of both Poland and Bulgaria were, to a great extent, a product of the Europeanisation and conditionality pre-accession processes. The reason for this was the limited development of these types of policies during communist rule, which mainly aimed at preventing unwanted emigration of their own citizens. ${ }^{2}$ The Europeanisation process that had already started after 1989 filled the 'institutional lacunae' of the communist legacy. ${ }^{3}$ Many institutions as well as legal and policy measures designed in Western Europe were transferred to Poland and Bulgaria as part of the Europeanisation process on the basis of policy transfer and

\footnotetext{
${ }^{1}$ Parts of this chapter were previously published in Vankova (2017).

${ }^{2}$ Grabbe (2006), p. 167; Kicinger et al. (2007), p. 181; Bobeva (1994), p. 222; Markova and Vankova (2014), p. 41.

${ }^{3}$ Grabbe (2006), p. 167.
} 
policy learning through various channels ${ }^{4}$ and led to the establishment of restrictive migration policies. ${ }^{5}$ This created a paradoxical situation, where the foundations of their migration policies were being laid in a top-down manner as a result of the conditionality pressure rather than being based on an actual necessity created by immigration processes. ${ }^{6}$

Even though both countries had to adapt to the EU conditionality, their approaches differed. In the field of Justice and Home Affairs, the Schengen acquis transferring rules on visa and borders was the EU policy that caused the most controversy at the national level because it had the potential to affect political and economic relations with neighbours and partners in Central and Eastern Europe (CEE). ${ }^{7}$ First of all, CEE countries were very sensitive to the possibility of creating a new 'Iron Curtain'. Secondly, both countries had close historical, cultural, and economic ties, albeit of a differing character, with countries like Ukraine and Russia. Nevertheless, both countries knew that failure to comply with Justice and Home Affairs conditionality could veto their EU accession and that they needed to respond to EU demands. ${ }^{8}$ As a result, the implementation of the EU visa policy at the national level is illustrative of the different strategies adopted by Poland and Bulgaria.

Poland's strategy was 'combative, involving tough negotiating stances and slow implementation of the policies that caused most domestic controversy'. ${ }^{9}$ Poland had a clear national interest when it came to its eastern borders. Cross-border trade was the main economic activity for many Polish citizens living at the eastern borders, as well as for many Ukrainians. With time, the difference between cross-border mobility and labour migration became vague ${ }^{10}$ and Ukrainians gradually began dominating certain types of jobs and occupations such as horticulture, housekeeping, and construction that were the least attractive employment niches for the Poles. ${ }^{11}$

Furthermore, the visa-free regime with Ukraine, Belarus and Russia, which was preserved after 1989, was based on the former 'socialist brotherhood' ties and reflected Poland's foreign policy interest in maintaining close contacts in the Eastern neighbourhood in order to achieve a stable and predictable geopolitical order in the region. ${ }^{12}$ Therefore, Poland's strategy was to postpone the introduction of the visa requirements for as long as it could and introduce them at the last possible moment. ${ }^{13}$ In addition, shortly before the pending changes, the Foreign Ministry launched an

\footnotetext{
${ }^{4}$ Kicinger and Koryś (2011), p. 371. See also Pawlak (2015).

${ }^{5}$ Lesińska et al. (2010), p. 67; Iglicka and Gmaj, (2013), p. 170; Jileva (2002), p. 81.

${ }^{6}$ Kicinger and Koryś (2011), p. 371.

${ }^{7}$ Grabbe (2006), p. 168. Another was the refugee protection system and the requirements of the Dublin II Regulation. In Kicinger and Koryś (2011), p. 372. See also Jileva (2002), p. 81.

${ }^{8}$ Ibid., p. 183.

${ }^{9}$ Ibid., p. 111.

${ }^{10}$ Stola (1998), p. 88.

${ }^{11}$ Okólski (2001), p. 102.

${ }^{12}$ Kicinger et al.(2007), pp. 188-189.

${ }^{13}$ Iglicka (2007), p. 265.
} 
information campaign encouraging people in neighbouring countries to apply for multi-entry visas to soften the impact of the visa requirements and the burden the new rules were expected to pose on administrative capacity. ${ }^{14}$

On the other hand, Bulgaria's approach was 'catch-up and imitation' ${ }^{15}$ The driving force behind this strategy was entrenched in the desire to leave the EU's negative visa list and show its EU partners that it could be trusted to implement the acquis. ${ }^{16}$ After the decision to lift EU visa requirements for Bulgarians was reached, the country introduced a visa regime for Ukraine faster than Poland, despite being further from an accession date. ${ }^{17}$ With regards to Russia, Bulgaria delayed the introduction of visas due to the special relations between the two countries. ${ }^{18}$ It sent a readmission agreement to Russia in an attempt to circumvent the visa problem, but since Russia did not have an agreement of this kind with any other country, this attempt failed and Bulgaria introduced visas for Russian citizens - again, years ahead of Poland. The economic effects of this decision were significant, especially with regards to trade with Russia, as well as tourism, which was very popular among Russians and Ukrainians. ${ }^{19}$

\subsection{National Instruments Fostering Circular Migration Developed After Accession to the $\mathbf{E U}$}

\subsubsection{Poland}

The policy measures and regulations fostering circular migration that Poland developed after its accession to the EU were to a great extent a response to the barriers erected by the Schengen acquis. ${ }^{20}$ Poland continued its pre-accession strategy as a participant in the EU decision-making process. It transferred its national foreign policy to the EU agenda and started advocating for a visa-free regime between the $\mathrm{EU}$ and the neighbouring countries from the Commonwealth of Independent States (CIS), incorporating them in the prevention of undesired migration to the EU and establishing exterritorial means of migration control. ${ }^{21}$ Along with Sweden, it initiated the European Union's Eastern Partnership, which, among others, provides for the gradual opening of the EU borders for citizens of these CIS countries on the

\footnotetext{
${ }^{14}$ Grabbe (2006), p. 174.

${ }^{15}$ Ibid., p. 111.

${ }^{16}$ Gros-Tchorbadjiyska (2010), p. 421; Grabbe (2006), p. 175; Jileva (2002), p. 81.

${ }^{17}$ Grabbe (2006), p. 175.

${ }^{18}$ Jileva (2002), p. 82; Gros-Tchorbadjiyska (2010), p. 255.

${ }^{19}$ Jileva (2002), p. 83.

${ }^{20}$ Iglicka and Gmaj (2013), p. 170.

${ }^{21}$ Müller (2014), p. 135.
} 
basis of agreements on mobility and security. ${ }^{22}$ In addition, with a view to Poland's accession to the Schengen area, the country supported the introduction of a separate local border traffic regime at the external borders of the $\mathrm{EU},{ }^{23}$ and signed a local border traffic agreement with Ukraine in $2008 .{ }^{24}$ The existing border traffic agreement between the two countries had to be renounced before the EU accession date. ${ }^{25}$

On a national level, after the visa introduction, Poland managed to secure its interests by liberalising the issuance of regular visas and the provision of no-fee visas for Ukrainian nationals and Russians residing in Kaliningrad until 2007, when the whole Schengen acquis was implemented. ${ }^{26}$ After that, in line with Poland's policy towards its eastern neighbours, citizens of Ukraine, Moldova, and Belarus were exempted from paying the consular fees for processing visa applications when applying for a Polish national visa (visa type D).

Furthermore, Poland's EU accession and the introduction of visas for Ukrainians had a strong impact on the availability of a flexible labour force provided in Poland based on the existing pattern of circularity of Ukrainian migrants; most had a legal stay in Poland because they did not need any visas to enter, but were in irregular employment due to the restrictive labour market legislation that made it very hard to obtain a work permit. ${ }^{27}$ The adoption of the EU acquis on migration control and irregular migration 'rendered the Polish "tacit tolerance" more difficult'. ${ }^{28}$

Greater economic growth combined with a diminished labour supply due to the massive exodus of Polish workers after the EU accession caused gaps in labour market sectors such as construction, agriculture, and horticulture. ${ }^{29}$ This strengthened the employers' organisations position to lobby for opening the labour market to foreign workers - which was echoed by politicians and quickly entered the public discourse.$^{30}$ All these factors, combined with the pressure exerted by farmers and fruit growers in need of foreign workers for the upcoming harvest, along with the participation of the farmers' party Samoobrona in the government coalition, led to the prompt introduction of a simplified procedure for hiring foreign workers referred in the text as the Oświadczenie procedure. ${ }^{31}$

Beyond the impact on the border regions, as a result of the implementation of the Schengen acquis the new visa regime was also perceived in the public debate as endangering relations with the Polish diaspora in the East. ${ }^{32}$ Therefore, after

\footnotetext{
${ }^{22}$ European Migration Network (2012), p. 32.

${ }^{23}$ Refer to Regulation (EC) No. 1931/2006 of the European Parliament and of the Council of 20 December 2006 laying down rules on local border traffic at the external land borders of the Member States and amending the provisions of the Schengen Convention [2006] OJ L 405.

${ }^{24}$ Kicinger et al. (2007), p. 189; Lesińska et al. (2010), p. 66. See Chap. 6, Sect. 6.3.1.

${ }^{25}$ Gros-Tchorbadjiyska (2010), p. 267.

${ }^{26}$ Kicinger et al. (2007), p. 189; Lesińska et al. (2010), p. 64.

${ }^{27}$ Müller (2014), p. 138.

${ }^{28}$ Ibid.

${ }^{29}$ Lesińska et al. (2010), p. 69.

${ }^{30}$ Ibid.

${ }^{31}$ Ibid, pp. 69-70; SOPEMI (2011), p. 310.

${ }^{32}$ Müller (2014), p. 148.
} 
Poland's accession to the EU, the country continued with its policy to strengthen ties with foreigners of Polish descent living abroad. ${ }^{33}$ It was no coincidence that the Pole's Card Act ${ }^{34}$ which was in the process of preparation since the late $1990 \mathrm{~s},{ }^{35}$ came into force on 29 March 2008, 1 day before the final step for full Schengen integration. ${ }^{36}$ The Act simplified the procedure for obtaining a multiple-entry national visa and exempted the holders thereof from paying Schengen visa fees. ${ }^{37}$

\subsubsection{The Simplified Oświadczenie Procedure}

The concept of circular migration did not officially become a national policy term until after the policy document 'Migration Policy of Poland: state of play and proposed actions' was adopted in 2012. ${ }^{38}$ The document stated:

'Conditions for legal circular migration should be created (for instance on the basis of visa facilitation), while at the same time ensuring the possibility of transposition, into Polish law, of certain solutions that are contained in the forthcoming Directive concerning admission of foreigners for seasonal work. It is worth emphasizing that circular migration, on the one hand, contributes to a decrease in the number of hired foreigners who do not possess work permit and reduces the phenomenon of illegal immigration. On the other hand, however, depending on the particular needs and through the use of appropriate actions and instruments, circular migration is a potential source of a verifiable permanent migration. It is also worth noting that circular migration does not undermine the human potential of sending countries and creates a favourable system of mutual economic and interpersonal relations'. ${ }^{39}$

This strategic document demonstrated the broad understanding of the concept by the Polish government as encompassing different instruments and not excluding permanent migration. It recommended the creation of proper conditions for circular migration, for instance through the further development of the Oświadczenie procedure, ${ }^{40}$ and thus linked the established simplified procedure to circular migration. The 2019 draft strategic document 'Migration Policy of Poland', which was

\footnotetext{
${ }^{33}$ Ibid.

${ }^{34}$ Act on the Pole's Card / Ustawa z dnia 7 września 2007 r. o Karcie Polaka (Dziennik Ustaw z 2019 r., poz. 1598). See Kozak et al. (2014), p. 188. This is a different procedure from the one determining Polish origin. For the differences, see ibid., pp. 185-189.

${ }^{35}$ Zogata-Kusz (2013), p. 160.

${ }^{36}$ The final integration step of Poland into the Schengen area occurred on 30 March 2008, when the border controls on internal EU flights were lifted. In Gros-Tchorbadjiyska (2010), p. 265.

${ }^{37}$ Ibid.

${ }^{38}$ Polityka migracyjna Polski - stan obecny i postulowane działania (2012), p. 9, p. 113, p. 122. This policy document was repealed in October 2016 and at the time of writing the Polish government had not yet adopted a new migration policy strategy. Council of Ministers (2012).

${ }^{39}$ See Chapter I: Legal migrations, Section 3-Labour migrations, 34 Subsection b: Recommendations (author's translation).

${ }^{40}$ Zogata-Kusz (2013), p. 216; European Migration Network (2011a), p. 13; Unterschütz (2016), p. 162.
} 
distributed only unofficially, also stressed that as a result of the introduction of the Oświadczenie procedure, an important channel for the inflow of economic migrants as part of legal circular migration had been launched. ${ }^{41}$ The draft document gave an indication of Poland's future migration policy, according to which circular migration that complements Poland's economic needs remains the preferred type of immigration. ${ }^{42}$ However, since immigration can contribute to Poland's economic development, it is advisable to treat circular migration as potentially leading to settlement, which forces reconciliation of immigration policy with integration policy. ${ }^{43}$

The report on circular migration, which was prepared by the Polish National Contact Point at the request of the European Migration Network in 2011, also highlighted the Oświadczenie procedure as one of the national instruments conducive to circular migration. ${ }^{44}$ It emphasised that the Oświadczenie procedure was not a 'circular migration instrument per se' or one of the typical circular migration programmes based on international bilateral agreements aiming to attract 'guest workers' ${ }^{45}$ Nonetheless, it had features that promoted this form of migration on the basis of national law, which amongst other things, facilitated access for foreigners to the Polish labour market. ${ }^{46}$

When asked how they understood the term circular migration, several interviewees representing different stakeholders directly referred to the Oświadczenie procedure that is operational between Poland and Ukraine as an example of such migration. ${ }^{47}$ Even though it is still 'not present expresis verbis in existing national legal acts' ${ }^{48}$ or developed as part of an official policy on circular migration, ${ }^{49}$ this is the primary national instrument that is considered to both 'represent' and promote circular migration, and thus is one of the national instruments that is assessed in this book.

The procedure was stipulated in a Regulation issued by the Minister of Labour and Social Policy, ${ }^{50}$ who was also a member of the Samoobrona party. The adoption

\footnotetext{
${ }^{41}$ Polityka Migracyjna Polski, Zespół do Spraw Migracji, Redakcja: Departament Analiz i Polityki Migracyjnej MSWiA, Draft of 10 June 2019, p. 6. Ministry of Interior and Administration (2019).

${ }^{42}$ Ibid., p. 55.

${ }^{43}$ Ibid.

${ }^{44}$ European Migration Network (2011a), p. 15, p. 19.

${ }^{45}$ Ibid., p. 5, p. 20. Also in Interview \# 1 with officials, Poland, November 2016, Annex II.

${ }^{46}$ Ibid., p. 18. Interview \# 15 with academic, Poland, November 2016, Annex II.

${ }^{47}$ Interview \#1 with officials, Poland, November 2016, Annex II; Interview \#2 with academic, Poland, November 2016, Annex II; Interview \#2 with official, Poland, November 2016, Annex II; Interview \#5 with civil society representative, Poland, November 2016, Annex II.

${ }^{48}$ European Migration Network (2011a), p. 8.

${ }^{49}$ Iglicka and Gmaj (2013), p. 170.

${ }^{50}$ Regulation of the Minister of Labour and Social Policy of 30 August 2006 regarding the performance of work by foreigners without the need to obtain a work permit / Rozporządzenie Ministra Pracy i Polityki Społecznej z dnia 30 sierpnia 2006 r. w sprawie wykonywania pracy przez cudzoziemców bez konieczności uzyskania zezwolenia na pracę (Dziennik Ustaw z 2006 r nr 156, poz. 1116).
} 
of a bylaw was the preferred approach by the Ministry because it was both expeditious enough to respond to farmers' pressing need for a flexible option that allowed for amendment in case the procedure needed to be changed ${ }^{51}$ and it also exempted workers from the general rule requiring work permits. As stressed by one of the interviewees, it did not require the approval of the whole cabinet or parliamentary scrutiny. ${ }^{52}$ Furthermore, it reflected the idea that Poland did not need an official labour migration policy and that the Oświadczenie procedure introduced was merely a temporary solution..$^{53}$

The procedure allowed workers from the neighbouring third countries to work in the agricultural and horticulture sectors without a work permit for a period of 3 months in every 6 months on the basis of a declaration of intent to entrust work to a foreigner. ${ }^{54}$ This programme expanded to all economic sectors in 2007 and the permissible work duration period was changed from 3 to 6 months in 12-month periods in 2008.$^{55}$ Furthermore, 2009 saw Moldova and Georgia being added to the list of countries that could benefit from this scheme as part of the initiatives under the Mobility Partnerships signed with them and different Member States, including Poland. ${ }^{56}$

In 2010, the Ministry of Labour and Social Policy took a decision to indefinitely extend the Oświadczenie procedure, which had initially been introduced as a pilot programme.$^{57}$ In 2014, Armenia joined the group of countries covered by this process. Currently the full list of countries whose citizens can benefit from Oświadczenie is provided in the Regulation of the Minister of Labour and Social Policy on the citizens of countries that are subject to certain provisions concerning a seasonal work permit, as well as provisions concerning the declaration on entrusting work to a foreigner ${ }^{58}$ on the basis of Article 90 (10) 2 of the Act on Employment Promotion and Labour Market Institutions. ${ }^{59}$

Registered abuses of the system led to changes in the procedure in 2018 in line with the new governmental Strategy for Responsible Development until 2020 (with

\footnotetext{
${ }^{51}$ Interview \#1 with officials, Poland, November 2016, Annex II.

${ }^{52}$ Interview \#15 with academic, Poland, November 2016, Annex II.

${ }^{53}$ Interview \#15 with academic, Poland, November 2016, Annex II.

${ }^{54}$ Kepinska and Kindler (2014), p. 274. Interview \#1 with officials, Poland, November 2016, Annex II.

${ }^{55} \mathrm{Ibid}$.

${ }^{56}$ Interview \#1 with officials, Poland, November 2016. See also 'Migration Policy of Poland: state of play and proposed actions', 2012, pp. 9, 122.

${ }^{57}$ SOPEMI (2011), p. 310.

${ }^{58}$ Rozporządzenie Ministra Rodziny, Pracy i Polityki Społecznej z dnia 8 grudnia 2017 r. w sprawie państw, do których obywateli stosuje się niektóre przepisy dotyczące zezwolenia na pracę sezonową oraz przepisy dotyczące oświadczenia o powierzeniu wykonywania pracy cudzoziemcowi (Dziennik Ustaw z 2017 r., poz. 2349)

${ }^{59}$ Act of 20 April 2004 on Employment Promotion and Labour Market Institutions / Ustawa o promocji zatrudnienia i instytucjach rynku pracy (Dziennik Ustaw z 2019 r., poz. 1482, consolidated text).
} 
a perspective to 2030$)^{60}$ as well as Poland's obligation to transpose the Seasonal Workers Directive, which was significantly delayed. The procedure, previously based on a Regulation issued by the Minister of Labour and Social Policy, ${ }^{61}$ was explicitly stipulated in the Act on Employment Promotion and Labour Market Institutions. In addition, the sectors of agriculture, forestry, fishery, services, gastronomy, and hospitality were excluded from the scope of the Oświadczenie procedure on the basis of the Regulation of the Minister of Family, Labour and Social Policy of 8 December 2017, which reserved these sectors for the holders of EU seasonal work permits. ${ }^{62}$ Another novelty introduced concerns the employer, who is currently obliged to inform the respective authorities whether the foreigner, for whom a declaration has been registered, has started the work in question or not (Article 88z (13) of the Act on Employment Promotion and Labour Market Institutions).

\subsubsection{Pole's Card (Karta Polaka)}

According to academic literature and the indications of the Polish focus group participants, another instrument that allows for the circulation of a special category of migrants is the Pole's Card (Karta Polaka). ${ }^{63}$ This became another 'gate' that migrants of Polish origin could use to gain access to their 'fatherland', along with the repatriation provisions regulated in the 2000 Act on Repatriation - the access to permanent settlement for foreigners who can prove that they are of Polish origin (in line with Article 52 (5) of the Polish Constitution) - and the scholarship opportunities for Polish students abroad. ${ }^{64}$ The scope of the Act on the Pole's Card was broader than the Act on Repatriation because it could be used by all foreigners of Polish origin from the former USSR, and not only those from the Asian parts of the

\footnotetext{
${ }^{60}$ Strategia na rzecz Odpowiedzialnego Rozwoju do roku 2020 (z perspektywą do 2030 r.), p.152. Council of Ministers (2017).

${ }^{61}$ In para 1 (20) of the Regulation of the Minister of Labour and Social Policy of 21 April 2015 concerning cases when commission of work to foreigners in the territory of the Republic of Poland is permitted without the requirement of obtaining a work permit/ Rozporządzenie Ministra Pracy $i$ Polityki Społecznej w sprawie przypadków, w których powierzenie wykonywania pracy cudzoziemcowi na terytorium Rzeczypospolitej Polskiej jest dopuszczalne bez konieczności uzyskania zezwolenia na pracę (Dziennik Ustaw z 2018 r., poz. 2273, consolidated text).

${ }^{62}$ Regulation of the Minister of Family, Labor and Social Policy of 8 December 2017 regarding activity subclasses according to the Polish Classification of Activities (PKD), in which seasonal work permits for a foreigner are issued/Rozporządzenie Ministra Rodziny, Pracy i Polityki Społecznej z dnia 8 grudnia 2017 r. w sprawie podklas działalności według Polskiej Klasyfikacji Działalności (PKD), w których wydawane są zezwolenia na pracę sezonową cudzoziemca (Dziennik Ustaw z 2019 r., poz. 1845 consolidated text).

${ }^{63}$ Kindler et al. (2016), p. 10. Focus groups with Russian and Ukrainian migrants, Warsaw, November 2016. Interview \#10 with staff member in private recruitment agency, Poland, October 2016.

${ }^{64}$ Lesińska et al. (2010), pp. 85-86
} 
country. ${ }^{65}$ The Pole's Card affirmed affinity to the Polish nation and applied to those who could not be granted Polish nationality because their countries of residence do not allow dual citizenship. ${ }^{66}$

Applicants for the Pole's Card have to demonstrate their links with Polish ancestry by possessing at least a basic knowledge of the Polish language, which they see as their mother tongue, and a knowledge and cultivation of Polish traditions and customs. ${ }^{67}$ They need to submit a written declaration of belonging to the Polish nation before a Polish consul, the Podlaski voivode, or designated proxy. ${ }^{68}$ In addition, the applicants need to prove that at least one parent or grandparent, or two great-grandparents, are or were of Polish nationality, or were Polish citizens. The requirement for proving Polish nationality can be replaced by an attestation from a Polish organisation or a Polish diaspora organisation that is active in one of the countries whose nationals are eligible to apply for the Karta Polaka, stating that the applicant had been actively involved in Polish cultural and linguistic activities within the Polish community in their region for a period of at least 3 years prior. ${ }^{69}$

Finally, applicants have to declare that neither they nor their ascendants have repatriated themselves or have been repatriated from the territory of the Republic of Poland or the Polish People's Republic on the basis of repatriation agreements concluded in the years 1944-1957 by the Republic of Poland or the Polish People's Republic with the Belarusian Soviet Socialist Republic, Ukrainian Soviet Socialist Republic, the Lithuanian Soviet Socialist Republic, or the Union of Soviet Socialist Republics onto the territory of one of the countries that were party to these agreements.

Until 2019, the countries whose citizens or non-citizen residents were eligible to apply for the Karta Polaka were Armenia, Azerbaijan, Belarus, Estonia, Georgia, Kazakhstan, Kyrgyzstan, Lithuania, Latvia, Moldova, Russia, Tajikistan, Turkmenistan, Ukraine, and Uzbekistan. ${ }^{70}$ Also eligible for the Karta Polaka were foreigners from one of the above-mentioned countries whose Polish origin has been established according to the procedure stipulated in the Act on Repatriation. Since July 2019, citizens of all countries can apply for Karta Polaka if they can

\footnotetext{
${ }^{65}$ Ibid., p. 87.

${ }^{66}$ Kepinska and Kindler (2014), p. 276.

${ }^{67}$ Kozak et al. (2014), p. 188.

${ }^{68}$ Since the amendments in 2017, the Council of Ministers may also designate a governor as the competent authority to receive applications for issuing a Pole's Card and indicating the states whose citizens will be eligible to submit their applications via this route. For more details, see Regulation of the Council of Ministers of 5 October 2017 regarding the appointment of a governor competent to conduct proceedings for granting or extending the validity of a Pole's Card, pursuant to Article 12 (4) of the Pole's Card Act/ Rozporządzenie Rady Ministrów z dnia 5 października 2017 r. w sprawie wyznaczenia wojewody właściwego w zakresie prowadzenia postępowań o przyznanie lub przedłużenie ważności Karty Polaka (Dziennik Ustaw z 2017 r., poz. 1900).

${ }^{69} \mathrm{Ibid}$. A list of such organisations can be accessed here: http://www.migrant.info.pl/organizacjepolskie-i-polonijne.html

${ }^{70}$ Article 2, second paragraph, Act on the Pole's Card.
} 
demonstrate their Polish origin and speak Polish. ${ }^{71}$ Foreigners who are granted a Karta Polaka are also entitled to apply free of charge for a permit to settle in Poland ${ }^{72}$ and since the amendments in 2017 can claim a 9-month financial allowance after submitting an application for a permanent residence permit (Article 8a.1 of the Act on the Pole's Card).

\subsubsection{Bulgaria}

Bulgaria did not respond as actively as Poland to the barriers introduced by the adoption of the Schengen acquis, postponing the introduction of visas only with regards to its closest neighbours until the country's EU accession. ${ }^{73}$ Bulgaria concluded bilateral intergovernmental agreements with North Macedonia and Serbia regarding mutual travel of their citizens, which allowed visas to be issued for the citizens of those countries at the border for a stay of up to 10 days. ${ }^{74}$ These agreements also provided for rules that can facilitate short-stay visas as well as the travel of citizens of North Macedonia and Serbia to Bulgaria. In addition, two more consulates were opened in Bitola (North Macedonia) and Nis (Serbia) respectively.

The 'catch-up and imitation' model continued after Bulgaria's accession to the EU, this time with regards to the accession to the Schengen Area. The process of Europeanisation advanced through a rushed 'copy and paste' transposition of EU law, which lead to restrictive and unpractical provisions. ${ }^{75}$ As one of the interviewed lawyers said: 'Bulgarian lawmakers create rules artificially and impose them on Bulgarian society even if they are not adapted to our reality'. ${ }^{76}$ A representative of the administration confirmed that the current state of the legal framework on legal and irregular migration showed that the integration of international and European legislation into Bulgarian law had led to fragmentation. ${ }^{77}$ The Act on Normative Acts ${ }^{78}$ imposed a requirement to perform an analysis of the existing legal framework on the relevant topic and, if necessary, amendments were proposed in order to avoid contradictory regulatory decisions. Despite that, the interviewee stressed that there were cases where the amendments had not passed through Parliament or legal acts

\footnotetext{
${ }^{71}$ Act of 16 May 2019 amending Act on the Pole's Card / Ustawa z dnia 16 maja 2019 r. o zmianie ustawy o Karcie Polaka (Dziennik Ustaw z 2019 r., poz. 1095).

${ }^{72}$ Article 195 (1) 3 and 9 AF.

${ }^{73}$ Gros-Tchorbadjiyska (2010), p. 269.

${ }^{74}$ Ibid., p. 267.

${ }^{75}$ Interview \#9 with lawyer, Bulgaria, July 2016, Annex III.

${ }^{76}$ Interview \#9 with lawyer, Bulgaria, July 2016, Annex III.

${ }^{77}$ Interview \#13 with state official, Bulgaria, September 2016, Annex III.

78 Закон за нормативните актове (SG No. 27/3 April 1973, last amendment SG No. 34/3 May 2016).
} 
had to be amended again due to an inaccurate or incomplete implementation of the requirements of European legislation. ${ }^{79}$

Unlike Poland, Bulgaria had not been an active Member State and acted primarily as 'a policy taker', meaning that it had generally followed the mainstream views in relation to the EU's migration policy. ${ }^{80}$ This was also confirmed by one of the interviewees who was previously engaged in the EU policymaking process: 'Every time we go to a meeting on integration and asylum, Bulgaria is absent. They don't really participate'. ${ }^{81}$ This could be attributed mainly to the weak administrative capacity in migration policy management and the pre-accession inertia as a 'policy taker', ${ }^{82}$ as well as the imposed Cooperation and Verification Mechanism ${ }^{83}$ and the efforts of Bulgaria to prove that it was a loyal EU Member State in line with the country's ambition to join the Schengen Area. ${ }^{84}$ The latter also explains why the country's approach to migration has been primarily 'securitised', e.g., based on anticipation of soft security challenges in this area. ${ }^{85}$

Even though the foundations for its development were laid because of the conditionality pressure, migration policy was established as a national public policy on a strategic level just after Bulgaria's accession to the EU ${ }^{86}$ Bulgaria developed four national migration strategies after 2007. The first, the National Strategy on Migration and Integration (2008-2015), claimed to set the grounds for the development of a consistent national policy on managing migration and integration. In fact, one of the main reasons for creating a strategy in this field could be found in the establishment of the EU general program on 'Solidarity and Management of Migration Flows' and the available funds for all EU Member States ${ }^{87}$ The second strategy adopted was the National Strategy in the Field of Migration, Asylum and Integration (2011-2020) developed as part of the Bulgarian government's efforts to meet the requirements of accession to the Schengen Area. ${ }^{8}$ In 2014 and 2015 two other strategies were developed, mainly in response to the refugee crisis resulting from the conflict in Syria.

Three of the national strategies on migration highlighted the fact that circular migration needed to be both encouraged and promoted. ${ }^{89}$ The following extract

\footnotetext{
${ }^{79}$ Interview \#13 with state official, Bulgaria, September 2016, Annex III.

${ }^{80}$ Lessenski (2009), p. 8, p. 46; Vankova (2011), p. 82.

${ }^{81}$ Interview \#12 with academic, Italy, May 2013, Annex III.

${ }^{82}$ Vankova (2011), p. 82.

${ }^{83}$ European Commission (2006), Decision of 13 December 2006 establishing a mechanism for cooperation and verification of progress in Bulgaria to address specific benchmarks in the areas of judicial reform and the fight against corruption and organised crime, 2006/929/EC, OJ L 354.

${ }^{84}$ Lessenski (2009), p. 46.

${ }^{85}$ Ibid.

${ }^{86}$ Krasteva et al. (2011).

${ }^{87}$ Angelov et al. (2011), p. 173.

${ }^{88}$ Markova and Vankova (2014), p. 42.

${ }^{89}$ Council of Ministers (2008), p. 26, p. 35; Council of Ministers (2011), p. 40; Council of Ministers (2015), p. 49.
} 
from the 2008 Strategy shows how Bulgarian policymakers had understood the concept of circular migration:

'The large-scale acceptance of third- country nationals is not a good solution and has to be avoided, as the experience of other countries shows. An organised and balanced reception of third country nationals is undertaken. Their return to the country of origin is regulated after the expiry of their contract. In this way the European initiative at the Community level for the promotion of the so-called ,circular" migration is implemented in practice'.$^{90}$

According to the report on circular migration prepared by the Bulgarian National Contact Point at the request of the European Migration Network (EMN), the notion of temporary and circular migration persisted in its strategic documents even though circular migration was not a priority of Bulgaria's migration policy. ${ }^{91}$ In most cases, 'circular migration' is referred to as an EU term that is derived from EU migration policy to which Bulgaria adheres to as part of its national strategy on migration. ${ }^{92}$

Furthermore, one of the interviewed officials stressed that this term had lately been forgotten at the EU level and that he had to remind his colleagues at high-level meetings that this concept existed - especially in the context of the GAMM. ${ }^{93}$ The interviewee stated that the EU had adopted this term, but that it was up to the national authorities to provide the concept with further substance: 'We need to rather see what is behind this term in practice; or more precisely, which existing processes can be likened to or classified as a section, subsection, or type of circularity' ${ }^{94}$ He understood this concept as primarily trying to avoid the negative effects of 'brain drain' 95 as it signified a process whereby persons moved between their country of origin and an EU Member State. According to this state official, the circular migration process would lead to a win-win situation where, on the one hand, the persons would be able to enhance their qualifications, acquire know-how, experience, knowledge, and skills while working in the destination country and assisting its economy; on the other hand, by returning from their country of destination, they could pass on this experience to others who would benefit from 'the enrichment' on the basis of the 'training of trainers' principle. ${ }^{96}$ This concept was described in a similar way by an interviewee working for an international organisation in Bulgaria. ${ }^{97}$

Unlike the interviewees in Poland, the interviewed stakeholders in Bulgaria did not immediately link this concept to a specific legal instrument or national policy.

\footnotetext{
${ }^{90}$ Council of Ministers (2008), p. 23.

${ }^{91}$ European Migration Network (2011b), p. 10.

${ }^{92}$ Council of Ministers (2008), p. 23; Council of Ministers (2011), p. 40; Council of Ministers (2015), p. 49.

${ }^{93}$ Interview \#1 with official, Bulgaria, July 2016, Annex III.

${ }^{94}$ Interview \#1 with official, Bulgaria, July 2016, Annex III.

${ }^{95}$ Interview \#1 with official, Bulgaria, July 2016, Annex III.

${ }^{96}$ Interview \#1 with official, Bulgaria, July 2016, Annex III.

${ }^{97}$ Interview \#12 with expert from international organisation, Bulgaria, June 2016, Annex III.
} 
Rather, they described it as something that was not taking place at present. One of the interviewed lawyers emphasised that she did not have any clients who had experienced problems as a result of their circulation because voluntary circulation was 'mission impossible'. ${ }^{98}$ Asked how the term circular migration was to be understood, another interviewee said that in order for the country to facilitate circular migration, politicians had to first gain an understanding that labour migration was necessary and that people who would come to work for this purpose had to be provided with a circle of rights. ${ }^{99}$ The interviewee stressed that in practice, however, this approach was not mentioned in the public, political, or legislative discourses. She added that, in the current climate, none of the politicians in the country were prepared or willing to clearly state that the country needed immigrants. ${ }^{100}$

The representative of one employers' organisation gave a similar response, stating that current Bulgarian politicians 'did not want to hear about migration'. ${ }^{101}$ This interviewee added that there was a large discrepancy between the actions of politicians and the administration because the latter was obliged to develop migration policies as a result of Bulgaria's legal obligations to the EU. Another interviewee, who represented a different employers' organisation, also stressed that the country 'unfortunately' needed foreign workers in specific sectors; ${ }^{102}$ the interviewee remarked that for business organisations it was better if this migration was of a temporary and circular character because this would better match the labour market's changing needs. Unlike other interviewees, this one opined that the current legal framework was facilitating circular migration. ${ }^{103}$ The trade union representatives, on the other hand, noted that the current legislation was 'fairly reasonable' and that they did not see the need for reforms in relation to the migration of thirdcountry nationals. ${ }^{104}$

Moreover, neither the Migration Strategies nor the EMN report on circular migration explicitly pointed to any national instruments that would support the implementation of the EU's circular migration approach in Bulgaria. The EMN report stressed that 'the understanding of optimal migration' was based on the notion of temporary and circular migration: 'the economic situation is very dynamic, the labour market is flexible; migration, which can quickly and precisely respond to its changing requirements, is seen as the best option'. ${ }^{105}$ Therefore, the EMN study concluded that some of the instruments that could be identified in the first 2008 Strategy - such as the determination of quotas or the identification of labour deficits in certain professions with the participation of social partners - pertained to the

\footnotetext{
${ }^{98}$ Interview \#8 with lawyer, Bulgaria, July 2016, Annex III.

${ }^{99}$ Interview \#9 with lawyer, Bulgaria, July 2016, Annex III.

${ }^{100}$ Interview \#9 with lawyer, Bulgaria, July 2016, Annex III.

${ }^{101}$ Interview \#6 with representative of employers' organisation, Bulgaria, August 2016, Annex III.

${ }^{102}$ Interview \#16 with representative of employers' organisation, October 2016, Annex III.

${ }^{103}$ They referred to Chapter II 'Labour Migration from third countries' of the ALMLM.

${ }^{104}$ Interview \#5 with trade union representative, July 2016, Annex III.

${ }^{105}$ European Migration Network (2011b), p. 12.
} 
notion of temporary migration. ${ }^{106}$ Previous research on this topic, as well as the interviews that were conducted as part of this study, however, highlighted the bilateral labour agreements as being among the main national instruments with the potential to encourage circular migration. ${ }^{107}$

Unlike Poland, which introduced the Pole's Card as a quasi-citizenship mechanism, Bulgaria provided a fast-track procedure for acquiring Bulgarian citizenship on the basis of Bulgarian ethnic origin ${ }^{108}$ and, over the years, developed numerous policies to attract and retain foreign citizens of Bulgarian origin, ranging from facilitated access to the labour market and permanent residence to scholarships to study in Bulgaria. ${ }^{109}$ For instance, persons of Bulgarian ancestry are exempted from the majority of obligations that one needs to meet under the general naturalisation regime: they only need to have reached the age of majority and not have been sentenced by a Bulgarian court for a premeditated crime of a general nature or subject to criminal proceedings for such a crime unless the person concerned has been rehabilitated (Article 15 (1) 1 of the Act on Bulgarian Citizenship ${ }^{110}$ ). Ethnic Bulgarian origin is certified through the State Agency for Bulgarians Abroad, inter alia, based on the birth certificates of applicants' parents and grandparents, their mother tongue, membership of a Bulgarian Church, school, or the former Bulgarian citizenship of their parents. ${ }^{11}$

Such communities of foreign citizens of Bulgarian origin are considered to reside inter alia in countries like the Czech Republic, Slovakia, Romania, Hungary, Serbia, Moldova, Ukraine, and Croatia, where they gained the status of national minorities. ${ }^{112}$ The biggest Bulgarian community in the Balkan region was considered to be located in North Macedonia. ${ }^{113}$ The 2018 Strategy stressed that these were foreigners 'who would have fitted without any difficulties in the Bulgarian society due to their knowledge of the Bulgarian language, customs, and culture'. ${ }^{114}$

\subsubsection{Bilateral Agreements}

With the 2008 Strategy, the government sought to pursue a 'balanced approach' based on the EU's circular migration concept, i.e., the return of the immigrants to their country of origin after the expiry of their employment contract had to be

\footnotetext{
${ }^{106}$ Ibid.

${ }^{107}$ Vankova (2009), p. 57. Interview \#1 with official, Bulgaria, July 2016, Annex III. See also Lessenski (2011), p. 10.

${ }^{108}$ For more details, see Smilov and Jileva (2009).

${ }^{109}$ For more details see Vankova (forthcoming).

110 Закон за българското гражданство (SG No. 136/18 November 1998, last amendment SG No. 77/18 September 2018).

${ }^{111}$ Smilov and Jileva (2009), p. 225.

${ }^{112}$ Council of Ministers (2008), p. 6. For more details see Vankova (forthcoming).

${ }^{113}$ Ibid., p. 5.

${ }^{114}$ Ibid., p. 17.
} 
regulated in advance. ${ }^{115}$ Apart from individual admission and sector quotas, bilateral labour migration agreements - where possible paired with a bilateral agreement for social security coordination - were envisaged as suitable mechanisms that were considered in line with EU trends. ${ }^{116}$

The bilateral agreements for exchange of labour were the main policy instrument for managing labour migration before, as well as after, the fall of the communist regime. The signing of such agreements was considered the preferred way to resolve labour market problems, regulate labour migration, and at the same time limit discrimination against Bulgarian workers in foreign labour markets. ${ }^{117}$ Therefore, it was not a surprise that this instrument was among the main policy mechanisms concerning admission of third-country nationals envisaged by the Strategy.

One interviewee, representing the state administration, stated that the Migration Strategies aimed to create a balance between the policies on immigration, emigration and those that were targeted at 'Bulgarians abroad'. ${ }^{118}$ Therefore, the 2008 Strategy envisaged the conclusion of 'bilateral agreements for labour migration regulation' with third countries, which were important in relation to the latter policy. ${ }^{119}$ This means that in the case of Bulgaria, the implementation of the EU's circular migration approach through bilateral agreements is aligned with the country's policy of attracting ethnic Bulgarians who, as already discussed above, are also the target group for facilitated permanent settlement policies and citizenship.

In 2008, the draft bilateral labour migration agreements developed on the basis of a template approved by the National Council on Labour Migration were sent to four countries - Moldova, Macedonia, Ukraine, and Armenia - and a process of consultation was initiated. ${ }^{120}$ According to public officials interviewed in 2010 as part of a study for the Open Society Institute in Sofia, and within the parameters of the current study, no agreements were ever signed due to the financial crisis. ${ }^{121}$

The last National Strategy on Migration, Asylum and Integration (2015-2020) stressed that Bulgaria had to temporarily apply stricter rules for access to the Bulgarian labour market in order to reduce the number of work permits issued and tackle rising unemployment in the country as a result of the economic crisis. ${ }^{122}$ It acknowledged, nevertheless, that when the country's economy recovers, bilateral labour migration agreements with specific third countries would be used as the main instrument for foreign labour recruitment. The Eastern Partnership countries were

\footnotetext{
${ }^{115}$ Vankova (2011), p. 73-4.

${ }^{116}$ Council of Ministers (2008), p. 28.

${ }^{117}$ SOPEMI (1993), p. 117.

${ }^{118}$ This term is usually used to refer to foreigners of Bulgarian origin rather than Bulgarian citizens who emigrated. For more details see Vankova (forthcoming).

${ }^{119}$ Interview \#1 with official, Bulgaria, July 2016, Annex III.

${ }^{120}$ Vankova (2011), p. 78.

${ }^{121}$ Ibid.

${ }^{122}$ Council of Ministers (2015), p. 37.
} 
identified once again as the countries suitable for concluding such agreements. ${ }^{123}$ The Strategy emphasised that EU instruments in the field of legal migration, such as the Blue Card and the Single Permit Directives, that were transposed in the country's legislation were not considered sufficient for enabling Bulgaria to compete economically and socially with other EU Member States as well as with global competitors such as the USA, Canada, and Australia in the race to attract the best specialists. ${ }^{124}$

In 2016, the adopted Act on Labour Migration and Labour Mobility (ALMLM) ${ }^{125}$ provided a section on the possibility to conclude these types of agreements, which were meant to create options for circular migration. ${ }^{126}$ As envisaged by the 2008 Strategy, priority was to be given to those countries with which there was an ongoing negotiation for the conclusion of bilateral social security agreements or had already signed such agreements (Article 62 (3) of the ALMLM).

In late June 2017, the government approved a framework labour migration agreement with Armenia, Moldova, and Ukraine. ${ }^{127}$ It was remarked that 'signing agreements with Armenia, Moldova and Ukraine will be an opportunity to provide workers for economic sectors where there is a shortage of labour'. ${ }^{28}$ So far, two bilateral labour agreements have been concluded with Armenia and Moldova. ${ }^{129}$ Negotiations of a draft agreement with Ukraine have commenced and the Council of Ministers has approved two draft agreements with Belarus and Georgia. In addition, two consultations on draft bilateral social security agreements with South Caucasus countries have been carried out. ${ }^{130}$

\subsection{Conclusions}

This chapter demonstrated that the EU's circular migration concept entered the migration policy agendas of Bulgaria and Poland as part of the policy transfer driven by the Europeanisation process. Depending on the national specifics, this concept was interpreted differently at the national level. In Poland it was understood broadly as encompassing various instruments and not excluding permanent settlement. In Bulgaria, on the other hand, this notion was interpreted as close to the guest-workers model, where migrants were expected to leave after the end of their contracts.

\footnotetext{
${ }^{123}$ Ibid., p. 37.

${ }^{124}$ Ibid., p. 39.

125 Закон за трудовата миграция и трудовата мобилност (SG No. 33/ 26 April 2016, last amendment No. 34/ 23 April 2019).

${ }^{126}$ See Chapter 5 of the ALMLM. Interview \#1 with official, Bulgaria, July 2016, Annex III.

${ }^{127}$ Mediapool.bg (2017).

${ }^{128}$ Ibid.

${ }^{129}$ National Council on Migration and Integration (2018), p. 3.

${ }^{130}$ Ibid.
} 
Bulgaria's and Poland's pre-accession models provide a background for the instruments developed to foster circular migration. Poland's 'combative' strategy, characterised by a strong national stance on maintaining existing close contacts in the Eastern neighbourhood, led to the development of instruments at both EU and national levels allowing for circular migration of migrants coming from the CIS region to a great extent as a reaction to the Schengen barriers created. In contrast, Bulgaria has mainly been a 'policy taker' at the EU level and resorted to bilateral agreements as the main instrument to facilitate circular migration, which has been a preferred model of labour migration management in Bulgaria since the communist regime. These agreements are targeting mainly states with communities of ethnic Bulgarians, including the Eastern partnership countries, in line with Bulgaria's national strategy to attract these foreigners for settlement as well as for circular migration purposes.

This book has so far illustrated that circular migration, as a concept, is an empty shell filled by a combination of EU instruments introduced in Chap. 4, as well as existing national instruments labelled as part of the circular migration umbrella, including ethnic origin-based policy solutions. These national approaches to circular migration, however, do not exist in a vacuum and in order to assess whether they promote rights-based circular migration, they need to be examined in more detail against the background of general admission legal frameworks, including the transposed EU labour migration directives as well as other policies pertinent to circular migration.

\section{References}

Angelov, G., Z. Vankova and I. Ivanova (2011) Conclusions and Recommendations. In I. Ivanova (ed.) Current Trends in Cross-border Workforce Migration and the Free Movement of PeopleEffects for Bulgaria. Open Society Institute, Sofia.

Bobeva, D. (1994) Emigration from and Immigration to Bulgaria. In H. Fassmann and R. Münz (eds.), European migration in the late twentieth century. Historical patterns, actual trends, and social implications. Hants: Edward Elgar Publishing, pp. 221-238.

Council of Ministers (2008) National Strategy of Republic of Bulgaria on Migration and Integration (2008-2015), adopted with Council of Ministers Protocol No. 22.21/5 June 2008, Sofia.

Council of Ministers (2011) National Strategy in the field of Migration, Asylum and Integration (2011-2020), adopted with Council of Ministers Decision No. 8.17/23 February 2011, Sofia.

Council of Ministers (2012) Migration Policy of Poland: state of play and proposed actions, adopted with Council of Ministers resolution on 31 July 2012, Warsaw. Repealed in October 2016.

Council of Ministers (2015) National Strategy in the field of Migration, Asylum and Integration (2015-2020), adopted with Council of Ministers Decision No. 437/12 June 2015, Sofia.

Council of Ministers (2017) Strategy for Responsible Development until 2020 (with a perspective to 2030), adopted by resolution of the Council of Ministers on 14 February 2017.

European Commission (2006) Decision of 13 December 2006 establishing a mechanism for cooperation and verification of progress in Bulgaria to address specific benchmarks in the areas of judicial reform and the fight against corruption and organised crime. 2006/929/EC, OJ L 354. 
European Migration Network (2011a) Temporary and Circular Migration in Poland: empirical evidence, current policy practice and future options in EU Member States. Prepared by the National Contact Point to the European Migration Network, Warsaw.

European Migration Network (2011b) Temporary and Circular Migration in Bulgaria: empirical evidence, current policy practice and future options in EU Member States. Research Study within the framework of the European Migration Network. Ministry of Interior of Republic of Bulgaria, Sofia.

European Migration Network (2012) Visa policy as migration channel in Poland. National Report. Prepared by the National Contact Point to the European Migration Network, Warsaw.

Grabbe, H. (2006) The EU's Transformative Power. Europeanization Through Conditionality in Central and Eastern Europe. Palgrave Studies in European Union Politics. London: Palgrave Macmillan UK.

Gros-Tchorbadjiyska, A. (2010) The Europeanization of Visa Policy: A Transfer of Sovereignty Shaped by enlargement. Leuven: Katholieke Universiteit Leuven.

Iglicka, K. (2007) Poland. In A. Triandafyllidou and R. Gropas (eds), European Immigration: A Sourcebook. $1^{\text {st }}$ edition. Farnham, UK: Ashgate, pp. 263-277.

Iglicka, K. and K. Gmaj (2013). Circular Migration Patterns between Ukarine and Poland. In A. Triandafyllidou (ed.), Circular migration between Europe and its neighbourhood: choice or necessity? Oxford: Oxford University Press, pp. 166-186.

Jileva, E. (2002) Larger Than the European Union: The Emerging EU Migration Regime and Enlargement. In S. Lavenex and E. M. Uçarer (eds), Migration and the Externalities of European Integration. Lanham, MD: Lexington Books, pp. 75-89.

Kepinska, E. and M. Kindler (2014) Poland. In A. Tryandafillidou and R. Gropas (eds), European Immigration: A Sourcebook. $2^{\text {nd }}$ edition. Farnham, UK: Ashgate, pp. 273-286.

Kicinger A. and I. Koryś (2011) The case of Poland. In M. Borkert, R. Penninx, and G. Zincone (eds), Migration Policymaking in Europe: The Dynamics of Actors and Contexts in Past and Present. IMISCOE Research Series. Amsterdam University Press, pp. 347-376.

Kicinger, A., A. Weinar and A. Gorny (2007) Advanced yet Uneven: the Europeanization of Polish Immigration Policy. In T. Faist and A. Ette (eds), The Europeanization of National Policies and Politics of Immigration: Between Autonomy and the European Union. London: Palgrave Macmillan, pp. 181-200.

Kindler, M., A. Kordasiewicz and M. Szulecka (2016) Care needs and migration for domestic work: Ukraine-Poland. Global Action Programme on Migrant Domestic Workers and their Families An ILO/UE project. Geneva: International Labour Office.

Kozak, I., M. Tota and B. Wojcik (2014) Long-term Residence of Foreigners in Poland in the Light of Act on Foreigners of 12 December 2013. In T. Sieniow (ed.), Prawo I Polityka Migracyjna II. Lublin: Rule of Law Institute Foundation.

Krasteva, A., I. Otova and E. Staykova (2011) Labor Immigration to Bulgaria. European Migration Network report. http://annakrasteva.wordpress.com/2011/02/09/labor-migration-in-bg/\#_ftn2 Accessed 1 December 2017.

Lesińska, M. et al. (2010) Migration Policy in Poland and its impact on the inflows and settlement of immigrants. In A. Górny, I. Grabowska-Lusińska, M. Lesińska and M. Okólski (eds), Immigration to Poland: Policy, Employment, Integration. Wydawnictwo Naukowe Scholar, Warszawa.

Lessenski, M. (2009) The EU New Member States as Agenda Setters in the Enlarged European Union. Country Report: Bulgaria. European Policies Initiative. Open Society Institute, Sofia.

Lessenski, M. (2011) Executive summary. In I. Ivanova (ed.) Current Trends in Cross-border Workforce Migration and the Free Movement of People - Effects for Bulgaria. Open Society Institute, Sofia.

Markova, E. and Z. Vankova. (2014) Bulgaria. In A. Tryandafillidou and R. Gropas (eds), European Immigration: A Sourcebook. $2^{\text {nd }}$ edition. Farnham, UK: Ashgate, pp. 41-54.

Mediapool.bg (2017) Valeri Simeonov: We accelerate the granting of Bulgarian citizenship, 56000 people have been waiting for a long time. http://www.mediapool.bg/valeri-simeonov-uskory- 
avame-davaneto-na-balgarsko-grazhdanstvo-56-000-dushi-chakat-otdavna-news265934.html Accessed 26 November 2017.

Ministry of Interior and Administration (2019) Poland's Migration Policy. Unofficial draft of 10 June 2019, Warsaw.

Müller, A. (2014) Governing mobility beyond the state: centre, periphery and the EU's external borders. Palgrave studies in European political sociology. London: Palgrave Macmillan.

National Council on Migration and Integration (2018) Report on the 2018 Action Plan for the implementation of the National Strategy in the field of Migration, Asylum and Integration 2015-2020.

Okólski, M. (2001) The transformation of spatial mobility and new forms of international population movements: Incomplete migration in Central and Eastern Europe. In J. W. Dacyl (ed.), Challenges of Cultural Diversity in Europe. Stockholm: CEIFO, pp. 57-109.

Pawlak, M. (2015) Research-Policy Dialogues in Poland. In P. Scholten, H. Entzinger, R. Penninx, S. Verbeek (eds), Integrating Immigrants in Europe: Research-Policy Dialogues. IMISCOE Research Series. Cham: Springer, pp. 253-273.

Smilov, D. and E. Jileva (2009) The politics of Bulgarian citizenship: National identity, democracy and other uses. In R. Bauböck, B. Perchinig and W. Sievers (eds), Citizenship Policies in the New Europe. Amsterdam University Press, pp. 211-246.

SOPEMI (1993) Trends in International Migration. SOPEMI Annual Report 1993. Paris: OECD.

SOPEMI (2011) International Migration Outlook 2011. Paris: OECD.

Stola, D. (1998) Poland as a Migration Middle Zone at the EU Eastern Border. In K. Hakola (ed.), Migration and Refugee Policy on the Eastern Border of the European Union. University of Jyväskylä, pp. 84-91.

Unterschütz, J. (2016) National Report on Implementation of EU Migration Directives in Poland. In R. Blanpain, F. Hendrickx and P. Olsson (ed.), National Effects of the Implementation of EU Directives on Labour Migration from Third Countries. Alphen aan den Rijn: Wolters Kluwer, pp. 161-192.

Vankova, Z. (2009) Subsection B.7: Migration. In A. Kavrakova and E. Markova (eds). The Unfinished Business of the Fifth Enlargement Countries. Country Report: Bulgaria. European Policies Initiative, Open Society Institute, Sofia.

Vankova, Z. (2011) Specifics of Migration Management Policies. In I. Ivanova (ed.) In I. Ivanova (ed.) Trends in Cross-border Workforce Migration and the Free Movement of People - Effects for Bulgaria. Open Society Institute, Sofia.

Vankova, Z. (2017) Implementing the EU's Circular Migration Approach: Legal and Migrant Perspectives on Entry and Re-Entry Conditions in Bulgaria and Poland. Robert Schuman Centre for Advanced Studies Research Paper No. RSCAS 2017/34. Florence: European University Institute.

Vankova, Z. (forthcoming) diaspora policies, consular services and social protection for Bulgarian citizens abroad. In J.-M. Lafleur \& D. Vintila (Eds.), Migration and social protection in Europe and beyond (volume 2). Comparing consular services and diaspora policies. Cham: Springer

Zogata-Kusz, A. (2013) Labour immigration policy in a country known for emigration: Poland's policy towards economic immigration after EU accession. Olomouc: Univerzita Palackého v Olomouci. 
Open Access This chapter is licensed under the terms of the Creative Commons Attribution 4.0 International License (http://creativecommons.org/licenses/by/4.0/), which permits use, sharing, adaptation, distribution and reproduction in any medium or format, as long as you give appropriate credit to the original author(s) and the source, provide a link to the Creative Commons license and indicate if changes were made.

The images or other third party material in this chapter are included in the chapter's Creative Commons license, unless indicated otherwise in a credit line to the material. If material is not included in the chapter's Creative Commons license and your intended use is not permitted by statutory regulation or exceeds the permitted use, you will need to obtain permission directly from the copyright holder. 